NBER WORKING PAPER SERIES

\title{
THE EFFECT OF DRUG PROHIBITION ON DRUG PRICES: EVIDENCE FROM THE MARKETS FOR COCAINE AND HEROIN
}

\author{
Jeffrey A. Miron \\ Working Paper 9689 \\ http://www.nber.org/papers/w9689
NATIONAL BUREAU OF ECONOMIC RESEARCH 1050 Massachusetts Avenue
Cambridge, MA 02138
May 2003

I am grateful to the Earhart Foundation for financial support and to Angela Dills for research assistance. I thank Elena Alvarez, Ernie Berndt, Shane Hunt, Mark Kleiman, Aviv Nevo, Ricardo Rocha, Fiona ScottMorton, Richard Spady, Juan Tecco, Norbert Telmon, and Francisco Thoumi for help in finding and understanding data, Carolyn Travers and Robert Janice of the DEA for help in obtaining and understanding the STRIDE data, and William Rhodes and Patrick Johnston for additional help with these data. I have received useful comments from smeinar participants at Boston University, Chicago, Clark, Dartmouth, Princeton, University of Illinois (Chicago), UCSD, and the MIT-Harvard IO workshop. Jonathan Baker, Jeanette Covington, Barry Crane, Jon Caulkins, David Friedman, Milton Friedman, Simon Gilchrist, Mark Kleiman, John Leahy, Steve Levitt, Rob MacCoun, Casey Mulligan, Sam Peltzman, Jim Poterba, Eric Rasmussen, Bob Rosenthal, Peter Reuter, Sherwin Rosen, Bruce Sacerdote, James Wilson and two anonymous referees provided useful comments or discussions. The views expressed herein are those of the authors and not necessarily those of the National Bureau of Economic Research.

(C2003 by Jeffrey A. Miron. All rights reserved. Short sections of text not to exceed two paragraphs, may be quoted without explicit permission provided that full credit including Cnotice, is given to the source. 
The Effect of Drug Prohibition on Drug Prices: Evidence from the Markets for Cocaine and Heroin

Jeffrey A. Miron

NBER Working Paper No. 9689

May 2003

JEL No.H11, H29, K42, L51, L65, L66

\begin{abstract}
This paper examines the effect of drug prohibition on the black market prices of cocaine and heroin. The paper examines the ratio of retail to farmgate price for cocaine, heroin, and several legal goods, and it compares legal versus black market prices for cocaine and heroin. The results suggest that cocaine and heroin are substantially more expensive than they would be in a legalized market, but to a lesser degree than suggested in previous research.
\end{abstract}

Jeffrey A. Miron

Department of Economics

Boston University

Boston, MA 02215

and NBER

jmiron@bu.edu 


\section{Introduction}

The effect of drug prohibition on drug prices is an important parameter in the debate over legalization versus prohibition. Existing analyses suggest that prohibition has raised prices dramatically, making drugs ten, twenty, or even hundreds of times more expensive than they would be if legal. ${ }^{1}$ From both theoretical and empirical perspectives, however, the standard conclusion is potentially too strong.

On the theoretical side, the presumption that prohibition raises drug prices implicitly compares prohibition to laissez-faire. The relevant comparison, however, is between prohibition and the taxation-cum-regulation regime that would apply if drugs were legal. Since black market suppliers face low marginal costs of evading tax and regulatory policies, given they normally hide their activities from law enforcement authorities, they enjoy a cost advantage that partially offsets the increased costs created by prohibition. In addition, prohibition differs from a taxation-cum-regulation regime in the amount of enforcement, the nature of compliance incentives, the degree of market power and the level of advertising. These differences can weaken or even reverse the standard presumption (Miron 2001).

\footnotetext{
${ }^{1}$ See, for example, Friedman (1972), Reuter and Kleiman (1986), Moore (1990), Nadelmann (1991), Morgan (1991), Koper and Reuter (1996), or Caulkins and Reuter (1998).
} 
On the empirical side, most analyses of prohibition and drug prices simply note that the raw materials used to produce drugs sell at low prices in producer countries while the finished products sell at high prices in consumer countries. $^{2}$ This approach does not account for the storage, transportation, distribution, and retailing costs that exist for any product, nor does it recognize that black market suppliers evade tax and regulatory costs typically incurred by legal suppliers. Thus, the difference between the farmgate price and the retail price overstates the effect of prohibition.

This paper reconsiders the relation between drug prohibition and drug prices. The results are qualitatively similar to those in the previous literature, but they suggest a less dramatic effect of prohibition. And by accounting for various factors that determine drug prices, the results provide more convincing evidence of these effects.

Section 2 presents data on the ratio of retail to farmgate price for cocaine, heroin, and legal goods such as chocolate, coffee, tea, beer, and tobacco. The data show that retail cocaine and heroin prices are hundreds of times the costs of the raw materials used to make these goods, consistent with

\footnotetext{
${ }^{2}$ A partial exception is Caulkins and Reuter (1998), who quantify the costs that would exist in the absence of prohibition and estimates the costs imposed by enforcement. They do not, however, account for the taxation and regulatory costs that are evaded by black market suppliers.
} 
earlier analyses. The data also show, however, that retail price is sometimes hundreds of times the farmgate price for legal goods as well. Thus, the high value of this ratio for cocaine and heroin does not by itself indicate a substantial effect of prohibition.

To infer the impact of prohibition from these data, one must decide which legal good provides an appropriate model for a legalized cocaine or heroin market. If the appropriate benchmark is relatively unprocessed goods, such as coffee beans in a grocery store, the data suggest that black market cocaine and heroin are perhaps hundreds of times their legalized prices. If the appropriate benchmark is more processed goods such as espresso at Starbucks, then the data suggest black market cocaine is 2 times the legal price while black market heroin is 6 times the legal price. The right model is likely between these extremes, but I suggest that the espresso benchmark is not implausible.

Section 3 examines the prices of legal cocaine, morphine, and heroin. Cocaine is currently prescribed as a topical anesthetic, while morphine is widely used as an analgesic. In addition, cocaine, morphine, and heroin are used legally for scientific, analytic, and research purposes. Quality considerations aside, black market cocaine is roughly the same price as legal cocaine, while 
black market heroin is roughly three times the price of legal heroin. Adjusting for a likely monopoly markup, the data imply that cocaine is four times more expensive than it would be in a legal market while heroin is perhaps nineteen times its legalized price.

Sections 2 and 3 thus suggest that current cocaine and heroin prices are substantially higher than they would be in a legal market, but to a lesser degree than suggested in earlier work. One reason for the difference is that earlier analyses assume prohibition causes the entire increase in price from farmgate to retail. In addition, earlier analyses fail to note that while prohibition imposes costs on black market suppliers, it facilitates evasion of costs typically borne by legal suppliers.

Section 4 therefore examines the costs incurred by legal suppliers but evaded or avoided by black market suppliers. These include taxes, environmental, safety, and health regulation, labor market regulation, and advertising expenditures, amongst others. The results suggest that such costs constitute about 50 percent of the price of legal products.

Section 5 then examines the costs imposed by prohibition enforcement. The results suggest that prohibition's effects on labor, capital, and materials costs are about the same magnitude as the tax and regulatory costs avoided 
by black market suppliers. The full effect of prohibition is larger if prohibition affects factor proportions or economies of scale. But the effects on factor prices are consistent with relatively modest overall effects.

Section 6 concludes.

\section{The Prices of Cocaine, Heroin and "Simi- lar" Products}

This section examines the effect of prohibition on drug prices by estimating the ratio of retail price to farmgate price for cocaine, heroin and several legal goods. Prohibition is not the only reason this ratio might differ across commodities; production, storage, transportation, distribution, and retailing costs all contribute to this ratio. But if the ratios for cocaine and heroin are consistently larger than those for legal goods, this suggests an important role for prohibition in raising drug prices. This ratio is also the main indicator of prohibition's impact employed in previous work.

\subsection{The Production and Pricing of Cocaine and Heroin}

Cocaine is an alkaloid of the coca plant. Extracting cocaine from coca involves the following steps (Morales 1989, pp.76-86):

1. Raw coca leaves are picked by hand, dried in the sun, and marketed. 
2. Dried coca leaves are mashed with water and sulfuric acid; this produces a brownish, acidic liquid that contains the cocaine alkaloid.

3. The acidic liquid is introduced into a new pit, where the acid is neutralized by adding a base. An organic solvent is added, after which a fluid that does not contain the solvent is decanted.

4. The second decanted fluid is added to a container of water and sulfuric acid; sodium carbonate is then added. A white substance forms at the bottom. This white substance, when dried, is coca paste.

5. The coca paste is crumbled and diluted in acetone; a fluid containing the alkaloid is then decanted. Hot air is added to evaporate the acetone, leaving the alkaloid condensate. This substance is pressed to remove water and resins; the remaining substance is cocaine base.

6. The cocaine base is diluted in acetone and mixed with acetone, ether and hydrochloric acid. The ether and acetone are decanted to leave the salt formed from cocaine base and hydrochloric acid. After drying, this substance is powdered, cocaine hydrochloride. 
Table 1 presents data on the price of coca leaf and cocaine. ${ }^{3}$ The first row displays the price in Peru of the amount of coca leaf necessary to produce a pure gram of cocaine hydrochloride (CHCL). The second row displays the retail price per pure gram of CHCL in the United States. The ratio of retail to farmgate price is 262 .

Heroin is a semi-synthetic compound derived from the opium poppy, $P a$ paver somniferum. Producing heroin from opium consists of the following steps (Krivanek 1988, p.106):

1. Incisions are made on the immature seed capsule. A milky exudate emerges; the dried exudate is brown, raw opium, which is marketed by the opium farmers.

2. Raw, brown opium is soaked, heated, and filtered; this produces a brown powder, which is morphine base or No. 1 heroin. It takes about $10 \mathrm{~kg}$ of opium to make $1 \mathrm{~kg}$ of morphine base, and $1 \mathrm{~kg}$ of morphine base produces about $1.1 \mathrm{~kg}$ of heroin (Lewis 1984).

3. Acetylation of the morphine base produces a powdery grey substance known as No. 2 heroin or heroin base. This is not water soluble and

\footnotetext{
${ }^{3}$ The data sources for all tables are given in an appendix that is available upon request. This information is also available in Miron (2001).
} 
not injectable.

4. No. 2 heroin can be refined into No. 3, or smoking heroin, a granular, soluble salt that can be grey, brown, bluish, or pink. This common form of heroin has a morphine content of about 30 percent.

5. No. 3 heroin can be refined further to give No. 4 heroin, a white powder. It can be up to 90 percent morphine.

Table 2 presents data on the price of opium and heroin. The first seven rows display the price in various countries of the amount of opium necessary to produce one gram of heroin. The final row gives the retail price of heroin in the United States. Assuming the amount of opium necessary to produce one gram of heroin costs $\$ 1.00$, the data imply a retail to farmgate ratio of 844.

\subsection{The Production and Pricing of Legal Goods}

I now examine the production and pricing of several legal goods. I focus on goods that are derived from agricultural products, that are produced in the same countries as cocaine and heroin, and that are distributed widely and purchased at the retail level by consumers for more or less immediate 
consumption. I return below to whether these goods are similar enough to cocaine and heroin to allow for meaningful comparisons.

Chocolate and cocoa are produced from cocoa beans, the seeds of the cocoa plant Theobroma cocoa. Producing chocolate and cocoa involves the following steps (International Cocoa Organization 1999):

1. The ripe pods of the cocoa tree are harvested by hand. These pods are the size of small melons and contain the cocoa seeds.

2. The pods are broken apart to extract the seeds and pulp. This occurs 7-10 days after the pods have been harvested.

3. The seed/pulp combination is stored in a warm place that allows yeast to break down the pulp, kill the beans, and produce other biochemical reactions that develop flavor and color. This takes 5-7 days.

4. The fermented beans are dried and marketed by farmers.

5. The beans are cleaned and roasted. The shells are removed from the roasted beans, which leaves the nibs. The nibs are alkalinized to develop color and flavor.

6. The nibs are crushed to produce cocoa liquor, which is cocoa particles suspended in cocoa butter. 
7. Some cocoa liquor is pressed to produce cocoa presscake, a solid mass, and cocoa butter; the presscake is pulverized to make cocoa powder.

8. The remaining cocoa liquor is made into chocolate by adding cocoa butter, sugar, milk, emulsifying agents, and other ingredients.

Table 3 provides data on the price of cocoa beans and chocolate products. ${ }^{4}$ The estimated ratio of retail to farmgate price is 88 for milk chocolate purchased at a drug store, 31 for regular cocoa powder purchased at a grocery store, 63 for Dutch-processed cocoa powder purchased at a grocery store, and 441 for a cup of hot chocolate purchased at a coffee bar.

Coffee is made from seeds of the coffee bush Coffea arabica (high quality coffee) or Coffea canephora (low quality coffee). Producing coffee involves the following steps (CoffeeUniverse 1999):

1. Pods (cherries) containing the coffee beans are harvested.

2. The beans (the seeds of the cherries) are removed.

3. The green beans are dried, sized, sorted, graded, and selected, then packed into bags for shipment to roasters.

\footnotetext{
${ }^{4}$ The remaining tables in the section report the implied price per unit of raw material at each stage, whereas Tables 1-2 report the implied price per unit of final good at each stage. This is for convenience and has no effect on the ratios.
} 
Table 4 provides data on the prices of coffee beans and coffee products. The estimated ratio of retail to farmgate price is 3-3.5 for roasted, ground beans, 7-8 for roasted, whole beans, 29-34 for a cup of coffee, and 126-148 for an espresso or espresso-based drink.

Table 5-7 summarizes similar information for a number of additional goods; Miron (2001) describes the production processes. The estimated ratio of retail to auction price is 8 for tea in a box of regular tea bags, 34 for the tea in a box of specialty tea bags, and 233 for the tea in a pot of tea. The estimated ratio of retail to farmgate price is $139-185$ for beer sold in a liquor store and 556 for beer sold in bars or restaurant. The estimated ratio of retail to farmgate price is 30 for the tobacco in cigarettes.

\subsection{Discussion}

The critical question in drawing conclusions from these data is which legal good provides a plausible model for legalized cocaine or heroin. One view is that the legalized market would resemble, say, ground coffee at the grocery store. Under this view, the data suggest cocaine is 80 times its legal price while heroin is hundreds of times its legal price. A different view is that the legalized market would resemble, say, the market for espresso at Starbucks. Under this view, the data suggest cocaine is only about twice its legal price 
while heroin is about six times its legal price.

In a legal market, drugs would presumably be available both in relatively unprocessed bulk quantities at low prices (e.g., bulk CHCL at drug stores) and in relatively processed small quantities at high prices (e.g., crack, smoking heroin, coca tea and opium drinks at bars and coffee shops). Thus, as with many legal goods, low and high prices would exist simultaneously for different versions of the commodity.

The transactions used to compute the price of black market cocaine and heroin, however, are for small quantities in relatively processed form (e.g., small amounts of crack). Thus, the more appropriate comparison is plausibly with the prices of the relatively processed legal products, such as espresso, implying effects of prohibition at the lower end of the range discussed above. This conclusion is not iron clad; the purchase of an espresso at Starbucks differs in many respects from purchase of cocaine at a crack house. But the fact that substantial retail to farmgate ratios exist for legal goods, including those with distribution and retailing patterns that are similar to what would plausibly exist for drugs in a legal market, at least raises the possibility that prohibitions effect is far smaller than indicated in previous research.

Independent of which comparison provides the right benchmark, there 
are a number of possible biases in the calculations reported above, and these suggest smaller rather larger effects of prohibition. First, more processing takes place before the first market transaction in the legal products than in the cases of cocaine and heroin, implying the retail-to-farmgate ratios are understated for legal goods. Second, the prices of legal goods in specialized locations, such as highway rest stops or movie theaters, are typically higher than those considered here. Third, the data source used to obtain price data likely overstates transactions prices faced by actual drug consumers as opposed to DEA agents (Miron (2001, pp.75-76)). ${ }^{5}$

A different issue is that the comparisons here implicitly assume legal drugs would be taxed and regulated like any other good. In practice, drugs would likely be subject to higher than usual taxation. Excessively high taxes would result in a black market, but experience with alcohol and cigarettes suggests taxes can raise prices by a factor of 2-3 without generating a black market.

The bottom line is therefore that previous analyses have overstated the effect of prohibition on prices, and under plausible assumptions this overstatement has been substantial.

\footnotetext{
${ }^{5} \mathrm{~A}$ possible bias in the other direction is that cocaine and heroin consumers might purchases small amounts at high per unit prices because they are liquidity constrained. An alternative explanation for such behavior is that consumers are committing to a low consumption rate.
} 


\section{The Price of Legal Cocaine, Morphine, and Heroin}

A different way to determine the effect of prohibition on prices is to compare black market and legal transactions. ${ }^{6}$ Cocaine is used legally in the United States as a topical anesthetic, mainly in the upper respiratory tract (Catterall and Mackie (1996, p.338)). In addition, cocaine is used legally for certain scientific, analytic, and research purposes. For example, small amounts of cocaine are used to test blood, urine and hair samples for the presence of cocaine metabolites. Heroin is not used legally as medicine in the United States but it is used for scientific, research and analytic purposes. ${ }^{7}$

\subsection{Prices for Legal Cocaine}

Table 8 provides data on the price of legal cocaine. The first four rows are from the Red Book, a standard catalogue of wholesale pharmaceutical prices used by pharmacists, hospital dispensaries, HMOs, and the like. These

\footnotetext{
${ }^{6}$ Moore (1990) and Morgan (1991) compare the price of legal and black market cocaine. The legal price quoted by Moore is substantially below the current legal price, but it is not based on a transaction in bulk cocaine. The price cited by Morgan is also substantially below the current legal price, but it is a price available to "investigators," which may not be the general, market price. Nevertheless, there appears to have been a substantial increase in the price of legal cocaine over the past decade.

${ }^{7}$ Cocaine and morphine are Schedule II drugs under the Controlled Substances Act of 1970. This means they have accepted medical uses and can be legally prescribed under certain conditions. Heroin is a Schedule I drug, which means it has no currently accepted medical use in the United States.
} 
are prices at which pharmaceutical manufacturers are willing to sell their products. The next four rows report the prices at which various companies buy or sell cocaine used in research, scientific, and analytical products. The last five rows give black market prices for various transactions sizes.

The data show that black market prices for cocaine are similar to legal prices; indeed, the legal price exceeds the black market price for some transaction sizes. ${ }^{8}$ This comparison is potentially misleading, however, because the legal prices probably include a monopoly markup. There is currently only one company that legally imports substantial amounts of coca leaf into the United States. This company extracts the cocaine in the form of paste and sells it to a second company. This second company refines the paste into bulk cocaine and sells it to other companies. The second company is thus the only legal manufacturer of bulk cocaine in the United States, which suggests its prices contain a monopoly markup.

A recent legal case provides information on this markup. In 1995, a company that purchases bulk cocaine from the U.S. manufacturer sought permission from the DEA to import from a European manufacturer selling at a lower price. Under current law, the DEA must allow importation if

\footnotetext{
${ }^{8}$ The comparisons between black market and pharmaceutical cocaine understate the price of pharmaceutical cocaine by about 11 percent, since these are prices for cocaine hydrochloride, which is 89 percent cocaine by weight (Grinspoon and Bakalar (1976, p.74)).
} 
"competition among domestic manufacturers is inadequate" (Federal Register 1998, p.28). The DEA compared the price of domestic and European cocaine, where at least two manufacturers exist, and concluded that "prices in the foreign markets are between thirteen and twenty-two percent of the domestic price for a kilogram of cocaine" (Federal Register 1998, p.38).

The estimate of the monopoly markup provided by the DEA investigation was based on transactions of at least 100 grams. Dividing the 100 gm price from Analytical Company \#3 by 5.7, the mid-point of the DEA estimates of the markup, implies the black market price of cocaine is four times the legal (competitive) price.

\subsection{Prices for Legal Morphine and Heroin}

Table 9 presents data on the legal and black market prices of morphine and heroin. The first seven lines give the price of prescription morphine from the Red Book. The price per gram ranges from $\$ 3.50$ to $\$ 10.61$. The next three lines give the price of morphine available for scientific and research purposes from the company Sigma-Aldrich. The price per gram, for a different set of transaction sizes, ranges from $\$ 62.20$ to $\$ 800.00$. The next line gives the price of heroin available from Sigma-Aldrich for scientific and analytical purposes. The price per gram for a $25 \mathrm{mg}$ transaction is $\$ 4680$. The last four lines 
give the price per pure gram of black market heroin for different transactions sizes.

The first issue in interpreting this information is that the price per pure gram of morphine from Sigma-Aldrich is markedly higher than that from the two Red Book sources. Holding transaction size constant, the price from Sigma-Aldrich is 5.9-10.9 times higher.

I assume that this premium reflects additional costs, such as guarantees about purity, related to the specific uses of the Sigma-Aldrich products. Assuming pharmaceutical heroin would be cheaper than the research quality heroin by a similar factor, this suggests using $4680 / 10.9$, or $\$ 429.36$, as the price per pure gram of heroin in legal transactions of roughly $25 \mathrm{mg}$.

The remaining issue is whether, as with cocaine, the legal prices reflect a monopoly markup. This is possible, but there are currently two companies that legally import opium and derivates into the United States (Stecklow and Karp 2000). Thus, the markup is plausibly smaller than for cocaine, but to err on the conservative side I assume it equals the cocaine markup of 5.7. Combining this with the assumption that the price of $25 \mathrm{mg}$ of heroin from Sigma-Aldrich should be deflated by a factor of 10.9 and comparing this to the price per pure gram for black market transactions that are roughly 25 
mg implies black market heroin is roughly 19 times the legal price.

An alternative approach to estimating the legal price of heroin is to combine information on the price of legal morphine with information on the comparative potency of heroin and morphine. As shown in Table 9, morphine is available from legal manufacturers for as little $\$ 3.50$ per gram in transactions of 100 grams. The price per gram for black market heroin transactions that are roughly 100 pure grams is $\$ 113$. Assuming that heroin is three times as potent as morphine (Krivanek 1988, p.106), this implies that black market heroin is 13 times the price of legal heroin. ${ }^{9}$

\subsection{Caveats}

One possible qualification to these results is that the black market prices are for goods whose quality might be low or uncertain. It is not possible to eliminate this concern, but several considerations suggest it is not of overwhelming importance. First, the analysis above controls for purity, the single most important aspect of quality. Second, black market suppliers have an incentive to provide quality to attract repeat business. Third, existing data suggest quality considerations are not overwhelming.

\footnotetext{
${ }^{9}$ This calculation ignores any costs of producing heroin from morhpine. Maher (1976, p.40) states that "heroin is approximately 4-8 times more potent than morphine when administered by injection," which would imply a lower ratio of black market to legal heroin prices.
} 
In 1996 approximately 4 million persons used cocaine, some of them many times, (U.S. Department of Justice 1998, Table 3.83, p.245), and there were 144,180 emergency-room episodes related to cocaine (U.S. Department of Justice 1998, p.253). Thus, there were about 3.6 emergency room-episodes per hundred persons who used cocaine. Of these 144,180 episodes, however, only $35 \%$ consisted of episodes caused by overdoses or unexpected reaction, as opposed to chronic effect, seeking detoxification, or withdrawal, and only episodes in the first two categories can reasonably be attributed to poor quality. ${ }^{10}$ Further, overdose and unexpected reaction can occur when quality is known; many persons consume high doses of alcohol, for example. Thus, the number of emergency-room episodes attributable to quality concerns is modest.

A second caveat is that drugs might be more available in a legalized market, suggesting the full price would drop more than the monetary price. Existing evidence, however, suggests drugs are already widely available. Over the 1985-1997 period, the percentage of high school seniors stating it was "fairly easy" or "very easy" to get cocaine (heroin) always exceeded $40 \%$ and frequently exceeded 50\% (20\%, 30\%) (U.S. Department of Justice 1998,

\footnotetext{
${ }^{10}$ The reason given for about $16 \%$ of the episodes is other/unknown reason. Distributing these cases proportionally amongst the remaining five categories would not have a substantial effect on the results.
} 
p.162). These responses suggest a fair degree of availability, since over the same period the percentage of high school seniors admitting to having used cocaine (heroin) in the previous twelve months ranged between $3.1 \%$ and $13.1 \%(0.4 \%$ and $1.2 \%)$ (U.S. Department of Justice 1998, p.237).

\section{The Costs of Producing Legal Drugs}

The results presented above suggest a more modest effect of drug prohibition on drug prices than presented in previous work. One possible explanation is that legal suppliers incur tax and regulatory costs that are evaded or avoided by black market suppliers. In this section, I examine the magnitude of such costs.

The most obvious cost evaded by black market suppliers is taxes and associated compliance costs. Assuming no barriers to labor and capital mobility, the differential in labor and capital costs between the legal and black market sectors equals the tax burden incurred by labor and capital in the legal sector.

In 1995, tax collections in the relevant categories equaled 26 percent of GDP (Miron (2001, pp.25-26)). Adjusting for the difference between gross and net output, or for the fact that capital supplied to the government and 
non-profit sectors is not taxed, would make the tax burden even larger. Likewise, accounting for compliance costs would increase the estimated burden on legal suppliers.

A second source of cost-increasing policies is environmental, safety, and health regulation. These policies impose direct costs in the form of compliance expenditures, and they potentially reduce productivity growth by altering firm input choices or reducing innovation. Direct compliance costs are modest in comparison to total firm costs (Berman and Bui 1999), but existing estimates suggest this regulation has reduced productivity growth by at least $0.10-0.20$ percentage points per year and possibly by as much as 1-2 percentage points per year (Miron (2001, pp.26-28)).

Assuming reduced productivity growth of 0.5 percentage points per year cumulated over twenty-five years (the period from the early 1970s, when this regulation began to bite, to the present), this regulation has reduced productivity, and thus increased price, by 13.3 percent. Assuming the manufacturing price is $75 \%$ of the retail price implies that environmental, safety, and health regulation have increased retail prices by about 10 percent. $^{11}$

A different cost avoided by black market suppliers is advertising. The im-

\footnotetext{
${ }^{11}$ Nevo (1998) estimates that the manufacturing price is $80 \%$ of the retail price for ready-to-eat cereals. Bulow and Klemperer (1999) estimate $58 \%$ for cigarettes.
} 
plication of these expenditures for cost and price is ambiguous a priori (Miron 2001). But any reduction in conventional advertising offsets increased costs necessitated by this reduction (e.g., violent turf battles), and it may imply price reductions that exceed the magnitude of the reduced expenditure. The scope for advertising in a legal market for cocaine or heroin might resemble that in the markets for soft drinks, alcohol, or cigarettes; advertising accounts for about 10 percent of revenues in the soft drink industry, $7-15$ percent in the alcohol industry, and 12 percent in the cigarette industry (Miron 2001, p.29).

Numerous other policies (minimum wage laws, anti-discrimination laws, collective bargaining laws, fees and permits, local zoning rules, liability insurance, and the like) almost certainly add a few percentage points more to the costs evaded or avoided by black market suppliers. Adding up these factors implies that legal price exceeds costs by a factor of roughly 2 .

\section{The Costs Imposed by Prohibition Enforce- ment}

Although black market suppliers evade many costs incurred by legal suppliers, they incur costs not levied on legal suppliers. In fiscal year 2000, federal expenditure for prohibition enforcement was approximately $\$ 11.7$ bil- 
lion, while state and local expenditure almost certainly exceeded $\$ 14.3$ billion and may have been as high as $\$ 50.2$ billion (Miron 2002). This might suggest that prohibition has a substantial effect on drug prices. I show here, however, that the costs imposed by enforcement are consistent with relatively modest effects of prohibition on prices.

The first cost imposed by prohibition is the wage premium paid to compensate employees for the risk of arrest, incarceration, injury, or death. Levitt (1999, personal communication) suggests that $\$ 10$ an hour is an upper bound on the wages paid to employees in the illegal drug sector; higher figures sometimes cited in the literature (e.g., Fagan 1996) correspond to the earnings of entrepreneurs, who put up their own money. ${ }^{12}$ Since many black market employees simultaneously work at minimum wages jobs (Levitt and Venkatesh 1998), the minimum wage is a lower bound on the earnings of these employees in the legal sector. Thus, wage costs are approximately double what they would be in a legal market. ${ }^{13}$

Prohibition also imposes costs on the owners of capital. Both physical and financial assets believed to have been used in the drug trade are seized by

\footnotetext{
${ }^{12}$ Levitt and Venkatesh (1998), Padilla (1992) and Bourgois (1995) also report low wages for workers in the black market drug trade.

${ }^{13}$ This conclusion is consistent with independent evidence in MacCoun and Reuter (1992), Lott (1992), Grogger (1995), and Kling (1999); see Miron (2001, pp.31-32).
} 
federal, state and local law enforcement authorities, and a substantial fraction of these assets are forfeited permanently. Over the period 1993-1997, seizures averaged at most $\$ 2.5$ billion per year (Miron 2001, pp.32-33).

To gauge the impact of these seizures on costs, I assume as a benchmark that the capital-output ratio in the drug sector is equal to the ratio of nonresidential private capital to private output in the overall economy. ${ }^{14}$ In 1996, this was approximately 1.25 (U.S. Census Bureau 1998, Table 890, p.559, and Table 716, p.452). ONDCP (1997a, p.3) estimates that 1995 sales in the illegal drug sector equaled $\$ 57.3$ billion 1996 dollars. Assuming a 1996 value of $\$ 60$ billion, this implies a capital stock of $\$ 75$ billion. Thus, asset seizures in 1996 equaled approximately 3.3 percent of the capital stock.

The third major cost imposed on drug traffickers is drug seizures. ONDCP (1997a, p.4) estimates that in 1995, 462-553 metric tons of CHCL were produced and destined for the United States; of this amount, foreign seizures amounted to 41 tons and federal seizures 98 tons, implying a seizure rate of 25-30 percent. Adding in state and local seizures would likely increase the seizure rate only moderately.

To determine the net impact of these three effects on the costs of produc-

\footnotetext{
${ }^{14}$ This is a strong assumption, but it is not clear which way it is biased; in some cases black market suppliers rely heavily on capital to evade law enforcement.
} 
ing drugs under prohibition, assume first that seized drugs are raw materials. Then write costs as

$$
C=w L+r K+q M
$$

where $C$ is total cost, $w$ is the wage rate, $L$ is labor, $r$ is the rental rate on capital, $K$ is capital, $q$ is the price of raw materials, and $M$ is the quantity of raw materials. The discussion above suggests that enforcement raises $w$ by a factor of about 2; that enforcement raises the required rental rate on capital by 3.3 percentage points, which is roughly 50 percent of the average real return on equity; and that enforcement raises the effective price of raw materials by no more than 50 percent. Combining these estimates implies enforcement raises price by at most a factor of two. Alternatively, assume that seized drugs are the finished product. Then costs are

$$
C=(w L+r K)(1+t)
$$

where $t$ is the seizure rate. In this case, the estimates imply that enforcement raises costs by at most a factor of three. These costs are roughly the magnitude of the tax and regulatory costs avoided by black market suppliers.

The full effect of prohibition-cum-enforcement is presumably larger than the factor of 2-3 suggested above, since the calculations ignore additional costs necessitated by prohibition (e.g., bribes) and the effect of prohibition 
on factor proportions or economies of scale. It is not obvious how large these additional effects might be, so the estimates in this section merely suggest that the tangible effects of enforcement are not so large as to render implausible the results above about legal versus illicit prices.

\section{Conclusions}

The analysis above suggests that the current prices of cocaine and heroin, while substantially higher than they would be in a legal market, are not as elevated as suggested by previous research. Taking into account both the farmgate to retail price differences and the legal versus illegal price comparisons, I estimate that the black market price of cocaine is 2-4 times the price that would obtain in a legal market while the black market price of heroin is 6-19 times the legalized price. In contrast, prior research has suggested that cocaine is 10 to 40 times its legal price while heroin is hundreds of times its legal price. Thus, my conclusion is qualitatively similar but quantitatively different from that in previous research.

The key question for future research is whether increased enforcement of a given prohibition raises prices, whatever the relation between the initial level of prices and those that would obtain under an alternative regime. 
The discussion above does not address this issue; moreover, it seems likely that increased enforcement should add costs and therefore increase price, independent of the considerations raised here.

The existing time-series data on drug prices and prohibition enforcement, however, appear inconsistent with this hypothesis. Over the past twentyfive years, the real, purity-adjusted prices of cocaine and heroin have fallen dramatically while enforcement has increased several-fold (Basov, Jacoboson, and Miron 2001). ${ }^{15}$ Moreover, production and consumption of drugs have if anything increased over the same time period. This combination of facts is a fertile topic for future research.

\footnotetext{
${ }^{15}$ Relatedly, Dinardo (1993) uses annual, state-level data on cocaine prices from STRIDE and cocaine use rates from the Monitoring the Future to examine the effect of cocaine seizures on price and consumption. He finds no evidence that this measure of enforcement raises price or reduces consumption. Similarly, Yuan and Caulkins (1998) find a generally negative time-series relation between the number of illegal drug seizures and the black market prices of cocaine and heroin.
} 


\section{References}

[1] Basov, Suren, Mireille Jacobson, and Jeffrey A. Miron (2001), "Prohibition and the Market for Illegal Drugs: An Overview of Recent History," World Economics, 2(4, Oct.-Dec.), 133-158.

[2] Berman, Eli and Linda T.M. Bui (1999), "Environmental Regulation and Productivity: Evidence from Oil Refineries," manuscript, Boston University.

[3] Bourgois, Philippe (1995), In Search of Respect: Selling Crack in El Barrio, Cambridge: Cambridge University Press.

[4] Bulow, Jeremy, and Paul Klemperer (1999), "The Tobacco Deal," Brookings Papers on Economic Activity, Microeconomics 1998, 323-394.

[5] Catterall, William A. and Kenneth Mackie (1996), "Local Anesthetics," in Goodman 86 Gilman's The Pharmacological Basis of Therapeutics, 9th edition, Joel G. Hardman and Lee E. Limbird, eds., New York: McGrawHill.

[6] Caulkins, Jonathan P. and Peter Reuter (1998), "What Price Data Tell Us about Drug Markets," Journal of Drug Issues, 28(3), 593-612. 
[7] DiNardo, John (1993), "Law Enforcement, the Price of Cocaine, and Cocaine Use," Mathematical and Computer Modelling, 17(2), 53-64.

[8] Fagan, Jeffrey (1996), "Gangs, Drugs, and Neighborhood Change," in Gangs in America, C. Ronald Huff, ed., Newbury Park: Sage Publications.

[9] Friedman, Milton (1972), "Prohibition and Drugs," Newsweek, May 1, 104.

[10] Grinspoon, Lester and James B. Bakalar (1976), Cocaine: A Drug and Its Social Evolution, New York: Basic Books.

[11] Grogger, Jeffrey (1995), "The Effect of Arrests on the Employment and Earnings of Young Men," Quarterly Journal of Economics, CX(1), February, 51-72.

[12] International Cocoa Organization 1999, Web Site, http://www.icco.org/.

[13] Kling, Jeffrey R. (1999), "The Effect of Prison Sentence Length on the Subsequent Employment and Earnings of Criminal Defendants," Woodrow Wilson School Discussion Paper \#208, Princeton University. 
[14] Krivanek, Jara (1988), Heroin: Myths and Reality, Sydney: Allen \& Unwin.

[15] Koper, Christopher S. and Peter Reuter (1996), "Suppressing Illegal Gun Markets: Lessons from Drug Enforcement," Law and Contemporary Problems, 59(1), 119-146.

[16] Levitt, Steven D. and Sudhir Alladi Venkatesh (1998), "An Economic Analysis of a Drug-Selling Gang's Finances," NBER WP \#6592.

[17] Lewis, Roger (1984), "The Illicit Traffic in Heroin: Introduction and Part I, Cultivation and Production," Druglink, Spring, 7-14.

[18] Lott, John R. Jr. (1992), "An Attempt at Measuring the Total Monetary Penalty from Drug Convictions: The Importance of an Individual's Reputation," Journal of Legal Studies, XXI(Jan.), 159-187.

[19] MacCoun, Robert and Peter Reuter (1992), "Are the Wages of Sin $\$ 30$ an Hour? Economic Aspects of Street-level Drug Dealing," Crime and Delinquency, 38(4), 477-491.

[20] Maher, John T. (1976), Opium and Its Derivatives, Drug Enforcement Administration, U.S. Department of Justice. 
[21] Miron, Jefrey A. (2001), "Prohibitions and the Prices of Prohibited Goods: Evidence from the Markets for Heroin and Cocaine," Industry Studies Working Paper No.105, Department of Economics, Boston University.

[22] Miron, Jeffrey A. (2002), "Drug Policy in the U.S.: An Economic Analysis," manuscript, Boston University.

[23] Moore, Mark H. (1990), "Supply Reduction and Drug Law Enforcement," in Drugs and Crime, Michael Tonry and James Q. Wilson, eds., Chicago: University of Chicago Press.

[24] Morgan, John P. (1991), "Prohibition is Perverse Policy: What Was True in 1933 is True Now," in Searching for Alternatives, Melvyn P. Krauss and Edward P. Lazear, eds., Stanford: Hoover Institution Press.

[25] Morales, Edmundo (1989), Cocaine: White Gold Rush in Peru, Tuscon: The University of Arizona Press.

[26] Nadelmann, Ethan A. (1991), "America's Drug Problem," Bulletin of the American Academy of Arts and Sciences, XLV(3), 24-40. 
[27] National Narcotics Intelligence Consumers Committee (1982), Narcotics Intelligence Estimate: The Supply of Drugs to the U.S. Illicit Market From Foreign and Domestic Sources in 1980 (With Projections Through 1984), Washington, D.C.: Drug Enforcement Administration.

[28] Nevo, Aviv (1998), "Measuring Market Power in the Ready-to-Eat Cereral Industry," NBER WP \#6387.

[29] Office of National Drug Control Policy (1997a), What America's Users Spend on Illegal Drugs, 1988-1995, Washington, DC: USGPO.

[30] Office of National Drug Control Policy (1997b), National Drug Control Strategy, 1997: Budget Summary, Washington, DC: USGPO.

[31] Office of National Drug Control Policy (1998), National Drug Control Strategy, 1998: Budget Summary, Washington, DC: USGPO.

[32] Padilla, Felix (1992), The Gang as an American Enterprise, New Brunswick: Rutgers University Press.

[33] Reuter, Peter (1988), "Quantity Illusions and Paradoxes of Drug Interdiction: Federal Intervention into Vice Policy," Law and Contemporary Problems, 51(1), 233-252. 
[34] Reuter, Peter and Mark A.R. Kleiman (1986), "Risks and Prices: An Economic Analysis of Drug Enforcement," in Tonry, M. and M. Norris (eds.), Crime and Justice: An Annual Review of Research, Vol. 7, Chicago: University of Chicago Press.

[35] Stecklow, Steve and Jonathan Karp (2000), "Poppy Fields of India Have a Place in the Sun, But It's Under Attack," Wall Street Journal, Monday, April 3.

[36] The Tea Council (1999), From Estate to Shelf, http://www.teacouncil.co.uk/estate.htm.

[37] UNDCP (1997), "Economic and Social Consequences of Drug Abuse and ILlicit Trafficking," Technical Paper \#6, United Nations International Drug Control Programme, Vienna.

[38] U.S. Bureau of the Census (1998), Statistical Abstract of the United States: 1998, Washington, D.C.: National Technical Information Services.

[39] U.S. Department of Justice, Bureau of Justice Statistics (1998), Sourcebook of Criminal Justice Statistics 1997, Washington, D.C.: USGPO. 
[40] Yuan, Yuehong and Jonathan P. Caulkins (1998), "The Effect of Variation in High-Level Domestic Drug Enforcement on Variation in Drug Prices," Socio-Economic Planning Sciences, 32(4), 265-276. 
Table 1

Prices for Coca Leaf and Black Market Cocaine

\begin{tabular}{|c|c|c|c|c|}
\hline Product & Date & Location & Market & $\begin{array}{l}\text { Price of Amount required } \\
\text { per pure Gram of CHCL }\end{array}$ \\
\hline $\begin{array}{l}\text { Coca Leaf } \\
\text { Cocaine }\end{array}$ & $\begin{array}{l}\text { Q3-Q4,1998 } \\
1998\end{array}$ & $\begin{array}{l}\text { Peru } \\
\text { US }\end{array}$ & $\begin{array}{l}\text { Farmgate } \\
\text { Retail }\end{array}$ & $\begin{array}{l}\$ 0.36-\$ 0.57 \\
\$ 122.00\end{array}$ \\
\hline \multicolumn{4}{|c|}{ ratio of retail to farmgate price } & 262 \\
\hline
\end{tabular}


Table 2

Prices for Opium, Morphine, and Black Market Heroin

\begin{tabular}{lllll}
\hline & & & & \\
Product & Date & Location & Market & $\begin{array}{l}\text { Price of Amount required } \\
\text { per pure Gram of Heroin }\end{array}$ \\
\hline Raw Opium & 1997 & Afghanistan & Farmgate & $\$ 0.28$ \\
Raw Opium & 1998 & India & Farmgate & $\$ 0.11-0.23$ \\
Raw Opium & 1999 & India & Farmgate & $\$ 0.12-0.29$ \\
Raw Opium & 1997 & Thailand & Farmgate & $\$ 2.89$ \\
Raw Opium & 1998 & Colombia & Farmgate & $\$ 3.64$ \\
Raw Opium & 1996 & Asia & Farmgate & $\$ 0.50-6.27$ \\
Raw Opium & 1996 & Latin America & Farmgate & $\$ 5.80$ \\
Heroin & 1998 & US & Retail & $\$ 844.28$ \\
& & & \\
\hline
\end{tabular}


Table 3: Prices for Chocolate and Products

\begin{tabular}{|c|c|c|c|c|}
\hline Product & Date & Location & Market & $\begin{array}{l}\text { Price per Pound } \\
\text { of Cocoa Beans }\end{array}$ \\
\hline Cocoa Beans & Q1, 99 & Cote d'Ivoire & Farmgate & $\$ 0.30$ \\
\hline Cocoa Beans & 1998 & London/NY & $\mathrm{Ex} / \mathrm{Im}$ & $\$ 0.76$ \\
\hline Milk Chocolate & 06/99 & Boston & Retail & $\$ 26.44$ \\
\hline Cocoa Powder, Regular & 08/99 & Boston & Retail & $\$ 9.40$ \\
\hline Cocoa Powder, Dutch & & Boston & Retail & $\$ 18.83$ \\
\hline Cup of Hot Chocolate & $08 / 99$ & Boston & Retail & $\$ 132.30$ \\
\hline \multirow{4}{*}{\multicolumn{4}{|c|}{$\begin{array}{l}\text { ratio of retail to farmgate price, Milk Chocolate } \\
\text { ratio of retail to farmgate price, Cocoa Powder, Regular } \\
\text { ratio of retail to farmgate price, Cocoa Powder, Dutch } \\
\text { ratio of retail to farmgate price, Hot Chocolate }\end{array}$}} & 88 \\
\hline & & & & 31 \\
\hline & & & & 63 \\
\hline & & & & 441 \\
\hline
\end{tabular}


Table 4: Prices for Coffee

\begin{tabular}{|c|c|c|c|c|}
\hline Product & Date & Location & Market & $\begin{array}{l}\text { Price per } \\
\text { lb Coffee }\end{array}$ \\
\hline Raw Beans (Arabica) & Q4, 1998 & Colombia & Farmgate & $\$ 0.75$ \\
\hline Raw Beans (Arabica) & Q4, 1998 & Brazil & Farmgate & $\$ 0.88$ \\
\hline Roasted Ground Beans & 08/99 & Boston & Retail & $\$ 2.60$ \\
\hline Roasted Whole Beans & $08 / 99$ & Boston & Retail & $\$ 6.36$ \\
\hline Cup of Coffee & 06/99 & Boston & Retail & $\$ 25.43$ \\
\hline Espresso Drink & $06 / 99$ & Boston & Retail & $\$ 111.30$ \\
\hline \multirow{4}{*}{\multicolumn{4}{|c|}{$\begin{array}{l}\text { ratio of retail to farmgate price, Roasted, Ground Beans } \\
\text { ratio of retail to farmgate price, Roasted, Whole Beans } \\
\text { ratio of retail to farmgate price, Cup of Coffee } \\
\text { ratio of retail to farmgate price, Espresso Drink }\end{array}$}} & $3-3.5$ \\
\hline & & & & $7-8$ \\
\hline & & & & 29-34 \\
\hline & & & & $126-148$ \\
\hline
\end{tabular}


Table 5

Prices for Tea

\begin{tabular}{lcccc}
\hline & & & & \\
Product & Date & Location & Market & $\begin{array}{c}\text { Price per } \\
\text { lb of Tea }\end{array}$ \\
\hline & & & & \\
Dried Tea & 1999 & Sri Lanka & Auction & $\$ 0.50-1.00$ \\
Box of Tea Bags, Regular & $07 / 99$ & Boston & Retail & $\$ 5.98$ \\
Box of Tea Bags, Specialty & $08 / 99$ & Boston & Retail & $\$ 25.69$ \\
Cup of Tea & $08 / 99$ & Boston & Retail & $\$ 174.83$ \\
& & & & \\
\hline & & & & 8 \\
ratio from auction to retail, Box of Tea Bags, Regular & 34 \\
ratio from auction to retail, Box of Tea Bags, Specialty & & 233 \\
ratio from auction to retail, Cup of Tea & & \\
& & & \\
\hline
\end{tabular}


Table 6

Prices for Barley and Beer

\begin{tabular}{|c|c|c|c|c|}
\hline Product & Date & Location & Market & $\begin{array}{c}\text { Price per } \\
\mathrm{kg} \text { of Barley }\end{array}$ \\
\hline Malting Barley & $04 / 99$ & United States & Farmgate & $\$ 0.096$ \\
\hline Case of Beer, Liquour Store & 08/99 & Boston & Retail & $\$ 13.32-17.78$ \\
\hline Bottle of Beer, Bar/Restaurant & $08 / 99$ & Boston & Retail & $\$ 53.33$ \\
\hline \multirow{2}{*}{\multicolumn{4}{|c|}{$\begin{array}{l}\text { ratio of retail to farmgate price, Beer in Liquour Store } \\
\text { ratio of retail to farmgate price, Beer in Bar/Restaurant }\end{array}$}} & $139-185$ \\
\hline & & & & 556 \\
\hline
\end{tabular}


Table 7

Prices for Tobacco

\begin{tabular}{lcccc}
\hline Product & Date & Location & Market & $\begin{array}{c}\text { Price per pound } \\
\text { of tobacco }\end{array}$ \\
\hline Cured Tobacco & 1998 & U.S. & Farmgate & $\$ 1.83$ \\
Cigarettes & $06 / 99$ & Boston & Retail & $\$ 55.23$ \\
\hline \multirow{4}{*}{ ratio of retail to farmgate price, Tobacco } & 30 \\
\hline
\end{tabular}


Table 8

Legal versus Black Market Prices for Cocaine

\begin{tabular}{llll} 
Market & Amount & Price & Price per pure gram \\
\hline Prescription, Mallinckrodt & $5 \mathrm{gm}$ & 324.19 & $\$ 64.84$ \\
Prescription, Mallinckrodt & $25 \mathrm{gm}$ & 1710.94 & 68.44 \\
Prescription, A-A Spectrum & $5 \mathrm{gm}$ & 335.00 & 67.00 \\
Prescription, A-A Spectrum & $25 \mathrm{gm}$ & 1650.00 & 66.00 \\
Research, Company 1 & $1 \mathrm{gm}$ & & 83.55 \\
Research, Company 2 & $10 \mathrm{gm}$ & 858.60 & 85.60 \\
Analytical, Company 3 & $100 \mathrm{gm}$ & & 49.30 \\
Analytical, Company 4 & $1 \mathrm{gm}$ & 112.25 & 112.25 \\
\hline Black Market & $1 \mathrm{gm}$ & & 106.82 \\
Black Market & $5 \mathrm{gm}$ & & 84.34 \\
Black Market & $10 \mathrm{gm}$ & & 69.98 \\
Black Market & $25 \mathrm{gm}$ & & 46.79 \\
Black Market & $100 \mathrm{gm}$ & & 34.29 \\
\hline
\end{tabular}


Table 9

Legal versus Black Market Prices for Morphine and Heroin

\begin{tabular}{lrrc}
\hline Market & Amount & \multicolumn{1}{c}{ Price } & Price per pure gram \\
\hline Morphine, Red Book, A-A Spectrum & $5 \mathrm{gm}$ & 28.50 & 5.70 \\
Morphine, Red Book, A-A Spectrum & $25 \mathrm{gm}$ & 95.00 & 3.80 \\
Morphine, Red Book, A-A Spectrum & $100 \mathrm{gm}$ & 350.00 & 3.50 \\
Morphine, Red Book, Mallinckrodt & $5 \mathrm{gm}$ & 53.05 & 10.61 \\
Morphine, Red Book, Mallinckrodt & $25 \mathrm{gm}$ & 265.25 & 10.61 \\
Morphine, Red Book, Mallinckrodt & $50 \mathrm{gm}$ & 530.05 & 10.60 \\
Morphine, Red Book, Mallinckrodt & $100 \mathrm{gm}$ & 1061.00 & 10.61 \\
Morphine, Sigma-Aldrich & $25 \mathrm{mg}$ & 20.00 & 800.00 \\
Morphine, Sigma-Aldrich & $1 \mathrm{gm}$ & 155.00 & 155.00 \\
Morphine, Sigma-Aldrich & $5 \mathrm{gm}$ & 311.00 & 62.20 \\
Heroin, Sigma-Aldrich & $25 \mathrm{mg}$ & 117.00 & 4680.00 \\
\hline Heroin, Black Market & $25 \mathrm{mg}$ & & 1444 \\
Heroin, Black Market & $1 \mathrm{gm}$ & & 484 \\
Heroin, Black Market & $5 \mathrm{gm}$ & & 275 \\
Heroin, Black Market & $100 \mathrm{gm}$ & & 113 \\
\hline
\end{tabular}

